\title{
Assessment of Land Use Land Cover at Mining Areas in Panadhro, Kachchh using Remote Sensing and GIS
}

\section{Kajal Joshi*, Nishith Dharaiya \\ Wildlife \& Conservation Biology (WCB) Laboratory, Department of Life Sciences, Hemchandracharya North Gujarat University, Patan (Gujarat) 384265, India \\ Study Area: Panadhro, Kachchh, Gujarat, India \\ Coordinates: $23.6825^{\circ} \mathrm{N} ; 68.7709^{\circ} \mathrm{E}$}

Key words: Supervised classification, Change detection.

\section{Abstract}

Land use and land cover is a very important factor to understand the relation between the human and the environment. Land cover change is a major keynote of global environmental change. The development of any region is dependent on the urbanization and industrialization; however, the development sometimes shows an adverse impact on the environment resulting in loss of biological wealth of an ecosystem. Panadhro and the surrounding villages like Fulara and Khanot of Kachchh district are having abundant of coal minerals. There are lots of changes in Land Use Land Cover (LULC) because of the exploration of the minerals in this area. Remote Sensing (RS) and Geographic Information System (GIS) are very effective tools for analysis of land use and land cover changes at a regional level. This research explains the use of RS and GIS technology for the detection of LULC changes in the study area. Image classification has been done by ERDAS imagine. It is observed that LULC changes have been detected in last 13 yrs. mainly in the open land followed by the water bodies. The study has been pointed out the various effects of coal mining activities on the land use.

some other factors affect the LULC of a particulararea. The information generated on landscape change and configuration help to analyze global ecological and environmental change.

Population growth and human activities like mining in Panadhro, Fulara and Khanot villages of Kachchh district, Gujarat- India are responsible for the LULC change and environmental degradation (Kaul \& Sopan, 2012). Because of the population growth, there is a loss of agriculture land. Coal mining plays a fundamental role in the development and progress of this region, but it has some adverse impact on humans and environment. Panadhro of Kachchh district has ample amount of coal minerals (Singh et al., 2011). There is a lot of changes in LULC because of the exploration of coal minerals and it adversely affects the environment of that region (Chitade \& Katyar, 2010). Remote sensing (RS), integrated with the geographic information system (GIS), provides an effective tool for analysis of land use and land cover changes at a landscape level. Remote sensing as a direct adjunct to field, playing an important role to study and assess the natural resources (Abbas et al., 2010). By 
understanding the dynamics of land use development in the past, managing the current situation with modern GIS tools, and modeling the future, one is able to develop plans for multiple uses of natural resources and nature conservation (Prakasam, 2010). Anthropogenic changes in land use and land cover are often assumed to be identical; they are rather quite different (Sreenivasulu et al., 2013). The main objective of this study is to evaluate and quantify land use land cover changes in Panadhro village and surrounding areas due to coal mining in last 13 years using the LISS III satellite image and its classification.

\section{Methodology:}

Study area: Panadhro and the surrounding villages Fulara and Khanot are belongs to Lakhpat Taluka of Kachchh district, on the northwestern part of Gujarat. The climatic condition in this region is considered to be of the semiarid type. Extreme temperature both in summer and winterare felt. The minimum and maximum temperatures recorded are $15.4^{\circ} \mathrm{C}$ in winter and $50.16^{\circ} \mathrm{C}$ in summer respectively. The average temperature of this region is about $32^{\circ} \mathrm{C}$. Rainfall is extremely scanty and is active from June to September with annual average rainfall of $29.2 \mathrm{~cm}$. The Panadhro village has population of around 10,00o as per the population census 2011, out of which around 3000 people are working in coal mines (www.census2o11.co.in). It is famous for its lignite mines, which were developed in early 1970 s and are run by Gujarat Mineral Development Corporation (GMDC) Limited (Singh et al., 2011). The town S. K. Varmanagar was developed very few kilometers away from Pandhro to fulfill the daily needs of mining community after the Pandhro mines were opened. The first unit of mines was commissioned in 1974 and operated by GMDC. The lease area of this lignite mine is about 1157 ha. The total exploration area is $11.33 \mathrm{~km}^{2}$. Lignite and limestone are mined in this area by using hydraulic excavators and dumper combination with subsidiary equipments like dozer, water sprinkler motor grader etc. (Plate-1) The product lignite coal is directly used in Akrimota thermal power station and Kuchchh lignite thermal power station. According to an estimate made by the experts this mine has deposits of around one million tones of lignite which would be explored by the GMDC on commercial basis on the lines of the work done at Panadhro since last three decades. Panadhro lignite mines have in all 10 million tones of underground lignite reserves while 90 million tones have been so far dug and sold to the industries in and outsidethe Gujarat (www.deshgujarat.com).

In this study, LISS-III satellite images of the year 2000 and 2013 was used and explored through supervised classification in ERDAS $^{\circledR}$ imagine (Alsaaideh et al., 2011). A supervised classification is a significant tool for the process derives statistical relationships between the input and the ground truth habitats (Basana \& Wodeyar, 2013).
The images are obtained from Bhaskaracharya Institute for Space Applications and Geo-Informatics (BISAG) and National Remote Sensing Centre (NRSC), Hyderabad. Ground-truthing was done by collecting GPS points for confirmation and georeferencing (Phukan et al., 2013, Varadharajan et al., 2012). Change detection for all the land use land cover classes was evaluated between both the satellite images. Among different classification algorithms, the maximum likelihood was used for supervised classification by taking 50 training areas for five major LULC class categories (10 training points for each LULC class) (Temesgen et al., 2014). The LULC classes include Agricultural Land, Built Up area, Open/Waste Land, Water bodies and Mining area (Table 1). ERDAS Imagine $^{\circledast} 2014$ and Arc GIS ${ }^{\circledR} 10.2$ were used for satellite image processing and LULC change analysis (Tiwari and Saxena 2011). Digital land use land cover classification through supervised classification method was performed for the LULC classification. Recoding method is also done for converting pixel value into a properclass. Area statistics of each land use category is calculated in hectors in attribute table in ERDAS Imagine ${ }^{\circledast}$ as suggested by Abate (2011) (Table 2). The rate of change was calculated for each LULC class using following formula given by Temesgen et al. (2014).

Rate of change (ha/year) $=(A-B) / C$

Where: $A=$ Recentarea of LULC in ha,

$\mathrm{B}=$ Previous area of LULC in ha,

$\mathrm{C}=$ Time interval between $\mathrm{A}$ and $\mathrm{B}$ in years

The classified images were edited on the basis of the ground truth data collected from the field and then final classified maps were prepared with assessing classification accuracy using accuracy assessment tool of ERDAS $^{\circledR}$ where LULC maps were used in raster format. By applying random points in accuracy assessment window we received accuracy report containing overall classification accuracy (Dwivedi et al., 2015). Image analysis operations have been carried out using GIS and finally, the changes in various LULC classes are obtained using post-classification comparison method. Error matrix and KAPPA analysis were done for accuracy assessment classification. The final map was prepared after the ground truth and changes were estimated in GIS (Tiwari \& Khanduri, 2011). The output was analyzed for land cover degradation and interpreted with ancillary data collected from various government agencies. The results obtained were used in order to assess the stress of land use on the ecosystem for the better natural resource management.

\section{Results and Discussion:}

The study depicts that, Panadhro has undergone a huge change in various land use categories from 2000 to 2013. The land use assessment depicts that the total area of 11238.2 ha in the year 2000 was classified into agricultural 


\section{RESEARCH ARTICLE}

land (24.6o \%), built-up area (2.56\%), open/wasteland $(67.07 \%)$ and water body $(5.77 \%)$. While in 2013, no change was detected in agriculture land and built up area; however open lands are reduced by 7.14\%. Moreover, 7.19 $\%$ of the land was converted in mining area which was not detected in 2000. The land use difference has been shown in Figure 1. Table 2 illustrates the LULC change in Panadhro from 2000 to 2013.

Table-1: Description of Land Use Land Cover Classes

\begin{tabular}{|c|c|}
\hline LULC & Description \\
\hline Agricultural land & $\begin{array}{l}\text { Areas allotted to rain fed and irrigated } \\
\text { cultivation, including fallow plots, } \\
\text { agricultural land mixed with some bushes, } \\
\text { trees and the scattered rural settlements } \\
\text { included thecultivated fields. }\end{array}$ \\
\hline uiltu & $\begin{array}{l}\text { Areas that have been populated with } \\
\text { residential, commercial, transportation } \\
\text { facilities, settlements, roads and tourist } \\
\text { places }\end{array}$ \\
\hline pe & $\begin{array}{l}\text { Area of thin soil, sand or mountainous or } \\
\text { hilly areas, almost has no vegetation cover or } \\
\text { degraded agricultural lands. }\end{array}$ \\
\hline Water bodies & $\begin{array}{l}\text { Areas covered by manmade small dams, } \\
\text { seasonal and permanent water bodies } \\
\text { (streams, rivers, lakes, reservoirsand sea). }\end{array}$ \\
\hline Mining area & $\begin{array}{l}\text { Areas that have been allotted for the open } \\
\text { cast mining }\end{array}$ \\
\hline
\end{tabular}

After- Abate (2011), Temesgen et al. (2014), Diallo et al. (2009), Solaimani et al. (2010)

\begin{tabular}{|c|c|c|c|c|c|c|c|}
\hline \multicolumn{8}{|c|}{$\begin{array}{l}\text { Table-2: Land Use Land Cover Changes in Panadhro } \\
\text { (2000- 2013) }\end{array}$} \\
\hline & $\begin{array}{l}\text { Land Use } \\
\& \text { Land } \\
\text { Cover Class }\end{array}$ & \multicolumn{2}{|c|}{$\begin{array}{l}\text { LULC Area } \\
\text { Year } 2000\end{array}$} & \multicolumn{2}{|c|}{$\begin{array}{l}\text { LULC Area } \\
\text { Year } 2013\end{array}$} & $\begin{array}{l}\text { Change } \\
\text { in ha } \\
2000-2013\end{array}$ & $\begin{array}{l}\text { Rate of } \\
\text { Change } \\
3 \text { (ha/yr) }\end{array}$ \\
\hline & & & & & & & \\
\hline & Built & 2 & t. & & & & \\
\hline & $\begin{array}{l}\text { Open/Waste } \\
\text { lands }\end{array}$ & 2 & 67.07 & 6734.8 & 59.93 & $3-8 c$ & -61 \\
\hline & Water bodies & 64 & & & & & -0.4 \\
\hline & Min & o & 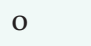 & 80 & 7.19 & 808.6 & 62.20 \\
\hline & Total & 2 & & 11238.2 & 100 & 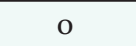 & o \\
\hline
\end{tabular}

The overall accuracy of classification methodology is $89.7 \%$ and $90.5 \%$ and KAPPA statistics is 0.87 and 0.88 respectively for the 2000 and 2013 images. The major land use in Panadhro and surrounding area of Kachchh is agricultural land, open land, water bodies, and settlements. But the land under the open category has experienced a declining trend in the past thirteen years. Here water bodies decrease and open land converted to the mining area. Table-2 depicts that almost all the mining areas are converted from the open land. There is a risk of decline in the extent of land under agriculture and built up in the near future. Changes in land use and land cover tend to affect greatly to the local biodiversity and the ecosystem. It is observed that because of changes in
Ambient Science, 2018: Vol. 05(2); 09-12 DOI:10.21276/ambi.2018.05.2.ra01

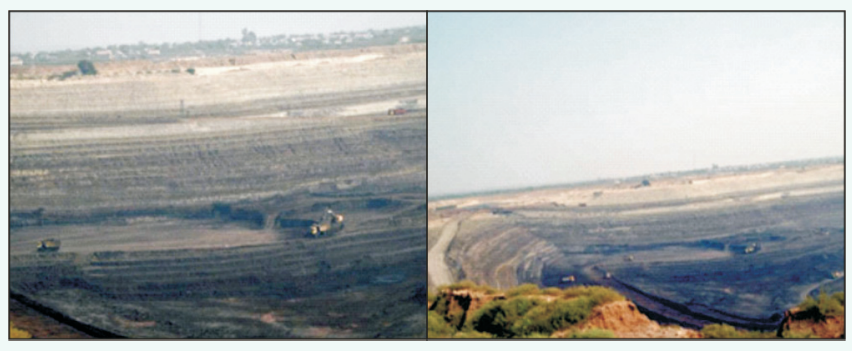

Plate-1:Panadhro coal mining site

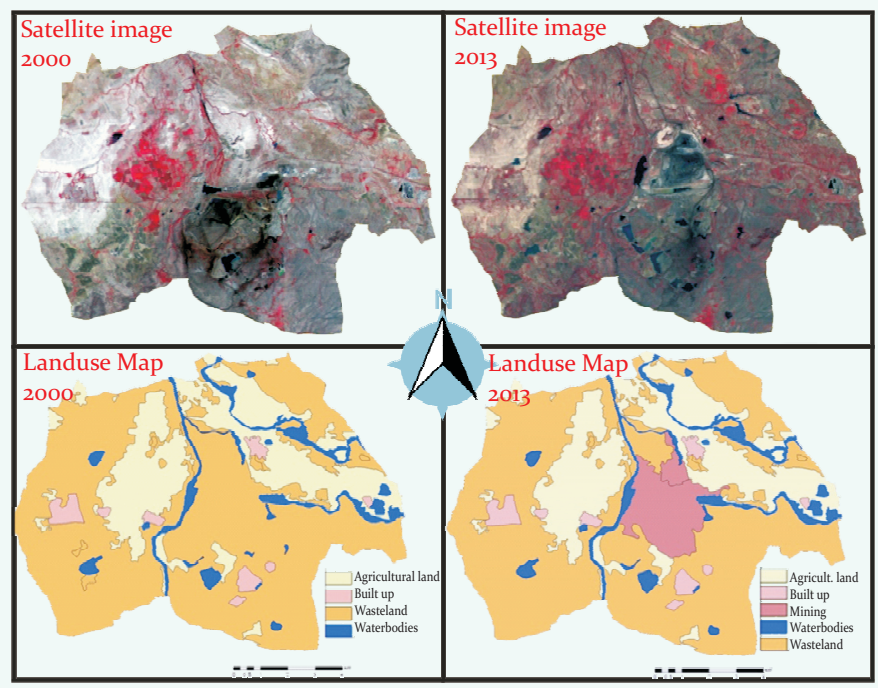

Figure-1: Satellite and classif ied images of year 2000 \& 2013

vegetation and water bodies, pollution level has increased extremely in the surrounding area and during the recent years, it has attained the critical level (Beniwal et al., 2015).

The results also reveal that there is a need to monitor the LULC changes at regular interval to prepare the land use plan for the sustainable development. The geological experts of GMDC have found a huge stock of lignite at Umarsar village near Panadhro spread in 2100 ha which has brightened new hope for industries in Kuchchh using lignite as fuel (Mengistu \& Salami, 2007). This area will also undergo the same situations as the Panadhro, which can be regulated through regular monitoring of LULC change using the techniques described in this research so that a suitable land management plan can be proposed for such areas affected by mining activities.

\section{Conclusion:}

The changes measured using remote sensing and GIS technologies shows critical adverse and undesirable environmental impacts. Therefore an effective sustainable land management policies and practices are required in the mining sites to avoid the environmental stress and promote sustainable development. The increase in the area under the mining may lead to a lot of environmental and ecological issues. As a sum up it could be stated that Panadhro area is now under the threat of change in land use. As the area is close to the Kachchh biosphere reserve it requires immediate attention. There 
is a need to take effective measures to protect the land especially open lands and water bodies in Kachchh region where the mining is now flourishing as an important industry.

\section{Acknowledgements:}

First author is thankful to Department of Science and Technology (DST), Government of India for the financial assistance vide reference no SR/WOS-A/ES-17/2014 under Women Scientist Scheme to carry out this work. Thanks are also due to BISAG for providing the satellite images and image analysis. Head, Department of Life Sciences, HNG University is duly acknowledged for providing the necessary facilities for the research work.

\section{References:}

Abate, S. (2011): Evaluating the Land Use and Land Cover Dynamics in Borena Woreda of South Wollo Highlands, Ethiopia.L.Sustain. Develop. Africa, 13(1): 87-105.

Abbas, I.I., Muazu, K.M. \& Ukoje, J.A. (2010): Mapping Land Useland Cover and Change Detection in Kafur Local Government, Katsina, Nigeria (1995-2008) Using Remote Sensing and GIS. Research, J. Environ. Earth Sci., 2(1): 6-12.

Alsaaideh, B., Al-Hanbali, A. \& Tateishi, R. (2011): Assessment of Land Use / Cover Change and Urban Expansion of the Central Part of Jordan Using Remote Sensing and GIS. Asian J. Geoinform., 11(3):1-9.

Basana, R. \& Wodeyar, A.K. (2013): Supervised Classification for LULC Change Analysis. Int. J. Comp. Appl., 66(21):24-26.

Beniwal, A., Sharma, M.P. \& Kumar, V. (2015): An Analysis of Land Use / Land Cover Change Detection Using Geospatial Technology-A Case Study of Rewari District, Haryana, India. Int. J. Emerg. Sci. Eng., 3(5):1-5.

Boakye, E., Odai, N., Adjei, A. \& Annor, O. (2008): Landsat Images for Assessment of the Impact of Land Use and Land Cover Changes on the Barekese Catchment in Ghana. Eur. J. Sci. Res., 22(2):269-278.

Chitade, A.Z. \& Katyar, S.K. (2010): Impact Analysis of Open Cast Coal Mines on Land Use / Land Cover Using Remote Sensing and GIS Technique: A Case Study. Int. J. Eng. Sci. Tech., 2(12): 7171-7176.

Diallo, Y., Hu, G. \& Wen, X. (2009): Applications of Remote Sensing in Land Use/Land Cover Change Detection in Puer and Simao Counties, Yunnan Province. J. Am. Sci., 5(4):157166.

Dwivedi, L., Sengupta, D. \& Tripathi, S. (2015): Change Detection Mapping of Land Use / Land Cover Area in Satna District: Using Remote Sensing and GIS Technique. Int. J. Multidisc. Res. Develop., 2(10):150-154.

Kaul, H.A. \& Sopan, I. (2012): Land Use Land Cover Classification and Change Detection Using High Resolution Temporal Satellite Data. J. Environ., 1(4):146-152.

Mengistu, D.A. \& Salami, A.T. (2007): Application of Remote Sensing and GIS in Land Use / Land Cover Mapping and Change Detection in a Part of South Western Nigeria. African J. Environ. Sci. Technol., 1(5): 099-109.
Nagarajan, N. \& Poongothai, S. (2011): Trend in Land Use/Land Cover Change Detection by RS and GIS Application. Int. J. Eng. Tech., 3 (4):263-269.

Phukan, P., Thakuriah, G. \& Saikia, R. (2013): Land use Land Cover Change Detection Using Remote Sensing and GIS Techniques -A Case Study of Golaghat District of Assam, India. Int. Res. J. EarthSci., 1(1):11-15.

Prakasam, C. (2010): Land Use and Land Cover Change Detection through Remote Sensing Approach: A Case Study of Kodaikanal Taluk, Tamil Nadu. Int. J. Geom. Geosci., 1(2):150-158.

Reis, S. (2008): Analyzing Land Use / Land Cover Changes Using Remote Sensing and GIS in Rize, North-East Turkey. Sensors, 8, 6188-6202.

Singh, P.K., Bhakat, D. \& Singh, G. (2011): Assessment of Groundwater Resources of Panadhro Lignite Mining Region, Gujarat State, India. Int. J. Environ. Sci., 1(7):1549-1558.

Sarma, P., Lahkar, B., Ghosh, S., Rabha, A., Das, J., Nath, N., Dey, S. \& Brahma, N. (2008): Land Use and Land Cover Change and Future Implication Analysis in Manas National Park, India using Multi-Temporal Satellite Data. Curr. Sci., 95(2): 1-5.

Solaimani, K., Arekhi, M., Tamartash, R. \& Miryaghobzadeh, M. (2010): Land Use / Cover Change Detection Based on Remote Sensing Data (A Case Study; Neka Basin). Agri. Biol.J. North Am., 1(6):1148-1157.

Sreenivasulu, G., Jayaraju, N., Pramod Kumar, M. \& Lakshmi Prasad, T. (2013): An Analysis on Land Use / Land Cover Using Remote Sensing and GISA Case Study In and Around Vempalli, Kadapa District, Andhra Pradesh, India. Int. J. Scien. Res. Pub., 3(5):1-4.

Temesgen, G., Amare, B. \& Abraham, M. (2014): Evaluations of Land Use / Land Cover Changes and Land Degradation in Dera District, Ethiopia: GIS and Remote Sensing based analysis. Int.J. Scient. Res. Environ. Sci., 2(6):199-208.

Tiwari, K. \& Khanduri, K. (2011): Land Use / Land Cover Change Detection in Doon Valley (Dehradun Tehsil), Uttarakhand, Using GIS and Remote Sensing Technique. Int. J. Geom. Gosci., 2(1):34-41.

Tiwari, M.K. \& Saxena, A. (2011): Change Detection of Land Use / Land Cover Pattern in an around Mandideep and Obedullaganj area, Using Remote Sensing and GIS. Int. J. Tech. Eng. Sys., 2(3):342-350.

Varadharajan, A., Iyappan, L. \& Kasinathapandian, P. (2012): Assessment on Land use Changes in Coimbatore North Taluk Using Image Processing and Geospatial Techniques. Int. J. Eng. Res. Appl., 2(4): 233-237.

Yanli, Y., Jabbar, M.T. \& Zhou, J. (2012): Study of Environmental Change Detection Using Remote Sensing and GIS Application: A Case Study of Northern Shaanxi Province, China. Pol. J. Environ. Sci., 21(3): 783-790. 